\title{
Gonadal function and fertility issues in Thalassaemia
}

\section{Nicos Skordis}

Makarios Hospital, Nicosia, Cyprus

\section{Oral presentation}

Oral presentation is available online

Correspondence: Nicos Skordis

CCopyright N. Skordis, 2013

Licensee PAGEPress, Italy

Thalassemia Reports 2013; 3(s1):e19

doi:10.4081/thal.2013.s1.e19

This article is distributed under the terms of the Creative Commons Attribution Noncommercial License (by-nc 3.0) which permits any noncommercial use, distribution, and reproduction in any medium, provided the original author(s) and source are credited.

Parts of this work were presented at the

"3rd Pan-European Conference on Haemoglobinopathies and Rare Anaemias", Limassol (Cyprus), 24-26 October 2012. 